\title{
A laboratory based experimental study of mercury emission from contaminated soils in the River Idrijca catchment
}

\author{
D. Kocman and M. Horvat \\ Jožef Stefan Institute, Department of Environmental Sciences, Jamova 39, 1000 Ljubljana, Slovenia
}

Received: 13 October 2009 - Published in Atmos. Chem. Phys. Discuss.: 25 November 2009

Revised: 26 January 2010 - Accepted: 31 January 2010 - Published: 8 February 2010

\begin{abstract}
Results obtained by a laboratory flux measurement system (LFMS) focused on investigating the kinetics of the mercury emission flux (MEF) from contaminated soils of the Idrija Hg-mine region, Slovenia are presented. Representative soil samples with respect to total $\mathrm{Hg}$ concentrations (4-417 $\mu \mathrm{g} \mathrm{g}^{-1}$ ) and land cover (forest, meadow and alluvial soil) alongside the River Idrijca were analysed to determine the variation in MEF versus distance from the source, regulating three major environmental parameters comprising soil temperature, soil moisture and solar radiation. MEFs ranged from less than 2 to $530 \mathrm{ng} \mathrm{m}^{-2} \mathrm{~h}^{-1}$, with the highest emissions from contaminated alluvial soils and soils near the mining district in the town of Idrija. A significant decrease of MEF was then observed with increasing distance from these sites. The results revealed a strong positive effect of all three parameters investigated on momentum MEF. The light-induced flux was shown to be independent of the soil temperature, while the soil aqueous phase seems to be responsible for recharging the pool of mercury in the soil available for both the light- and thermally-induced flux. The overall flux response to simulated environmental conditions depends greatly on the form of $\mathrm{Hg}$ in the soil. Higher activation energies are required for the overall process to occur in soils where insoluble cinnabar prevails compared to soils where more mobile $\mathrm{Hg}$ forms and forms available for transformation processes are dominant.
\end{abstract}

\section{Introduction}

Due to its volatile nature, mercury $(\mathrm{Hg})$ emission from terrestrial and aquatic surfaces is an important part of its biogeochemical cycle (Schroeder and Munthe, 1998; Schlüter,

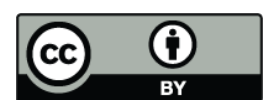

Correspondence to: D. Kocman (david.kocman@ijs.si)
2000). Mercury is released to the atmosphere from a multitude of anthropogenic and natural sources. On the global scale the contribution from anthropogenic sources ranges between 1200 and $2900 \mathrm{tyr}^{-1}$ (UNEP, 2008), whereas emissions from natural sources (i.e., volatilization from water surfaces, volcanoes, re-emissions from topsoil and vegetation) may represent the major contribution (up to $5200 \mathrm{t} \mathrm{yr}^{-1}$ ) to the global atmospheric mercury budget (Pirrone et al., 2008). Most of the $\mathrm{Hg}$ emitted to the atmosphere is in the form of elementary mercury vapor $\left(\mathrm{Hg}^{0}\right)$. Due to its low solubility and chemical stability, $\mathrm{Hg}^{0}$ can remain in the atmosphere for as long as 1-2 years, thereby enabling its dispersion and transport over large distances, regionally and even globally (Bergan and Rodhe, 2001; Lin and Pehkonen, 1999; Schroeder and Munthe, 1998).

Contaminated sites such as abandoned $\mathrm{Hg}$ mining areas and surrounding geologically enriched terrains can be regarded as substantial atmospheric mercury emission sources (Mason et al., 1994; Rytuba, 2003; Gustin, 2003). In recent years, considerable progress in understanding mercury geochemistry at such sites has been made with the development of interfacial mercury flux measurement technology (Ferrara et al., 1998a; Ferrara et al., 1998b; Gustin et al., 1996; Nacht et al., 2004; Gustin, 2003; Engle et al., 2001). Mercury emission rates from these $\mathrm{Hg}$-enriched areas were found to be greater than previously estimated, indicating that these sources may be more significant contributors of mercury to the atmosphere than previously realized (Gustin et al., 2000; Gustin, 2003; Engle et al., 2001; Wang et al., 2005, Wang et al., 2007a, Wang et al., 2007b; Coolbaugh et al., 2002; Feng et al., 2005). However, estimations of the quantitative significance of $\mathrm{Hg}$ emission relative to other pathways are very uncertain and too little is known about the amounts and species of mercury emitting from soil as well as factors causing and affecting this process (Schlüter, 2000), especially at contaminated sites. 
Here, we investigated factors controlling $\mathrm{Hg}$ release from soils collected from the Idrija mercury mine area, Slovenia. This area has been anthropogenically disturbed during 500 years of mercury mining activities which have resulted in significant $\mathrm{Hg}$ contamination of surrounding local environments. In the Idrija ore deposit, $\mathrm{Hg}$ uniquely occurs as both as cinnabar $(\mathrm{HgS} \sim 70 \%)$ and to a relatively smaller extent in the form of native mercury $\left(\mathrm{Hg}^{0} \sim 30 \%\right)$. The distribution of $\mathrm{Hg}$ in this area in various environmental compartments has been extensively studied in the past (Grönlund et al., 2005; Horvat et al., 2002; Hines et al., 2006; Biester et al., 2002; Gosar et al., 2006; Žižek et al., 2007; Kotnik et al., 2005). Mercury fractionation study of contaminated soils in the town of Idrija performed by Kocman et al. (2004) indicated cinnabar as the predominant $\mathrm{Hg}$ fraction in these soils, especially in coarse grained alluvial soils where on average it constituted more than $80 \%$ of total $\mathrm{Hg}$. Similar, Gosar et al. (2006) observed relatively enriched cinnabar bound mercury in soils closer to the pollution sources in the town of Idrija, while at locations more distant from the pollution sources, soils were found to be enriched in non-cinnabar mercury forms (Gosar et al., 2006). Kotnik et al. (2005) investigated the spatial distribution of $\mathrm{Hg}$ in the town of Idrija and measured mercury emission from topsoil using the in situ "flux chamber" technique. In their study, a strong influence of weather conditions, soil and air temperature, as well as air and soil $\mathrm{Hg}$ concentrations on $\mathrm{Hg}$ emission and distribution was observed. Grönlund et al. (2005) estimated the average mercury flux from the most polluted sites in the town of Idrija to be approximately $2-4 \mathrm{gh}^{-1}$, using the differential absorption lidar technique. Furthermore, simulation of mercury evaporation from different soil types from the Idrija region was performed and complemented by a selective sequential extraction procedure in order to assess the potential for mercury volatilization by Kocman et al. (2004). In that study the effect of soil temperature, soil moisture, as well as specific mercury binding in soil on its volatilization was observed. The results of all previous studies emphasised that still too little is known about the amounts of mercury evaporating from soils in the Idrija region, as well as the factors causing and affecting this process. For scaling-up and modelling of mercury evaporation from soils a comprehensive assessment of the processes controlling the evaporation of mercury from soils is imperative. Therefore, in the present study, mercury evaporation from soil was studied in more detail. The laboratory flux measurement system (LFMS) designed by Bahlmann et al. (2006) was used to directly measure the mercury emission flux (MEF) under controlled simulated environmental conditions, including soil temperature, soil moisture and solar radiation.

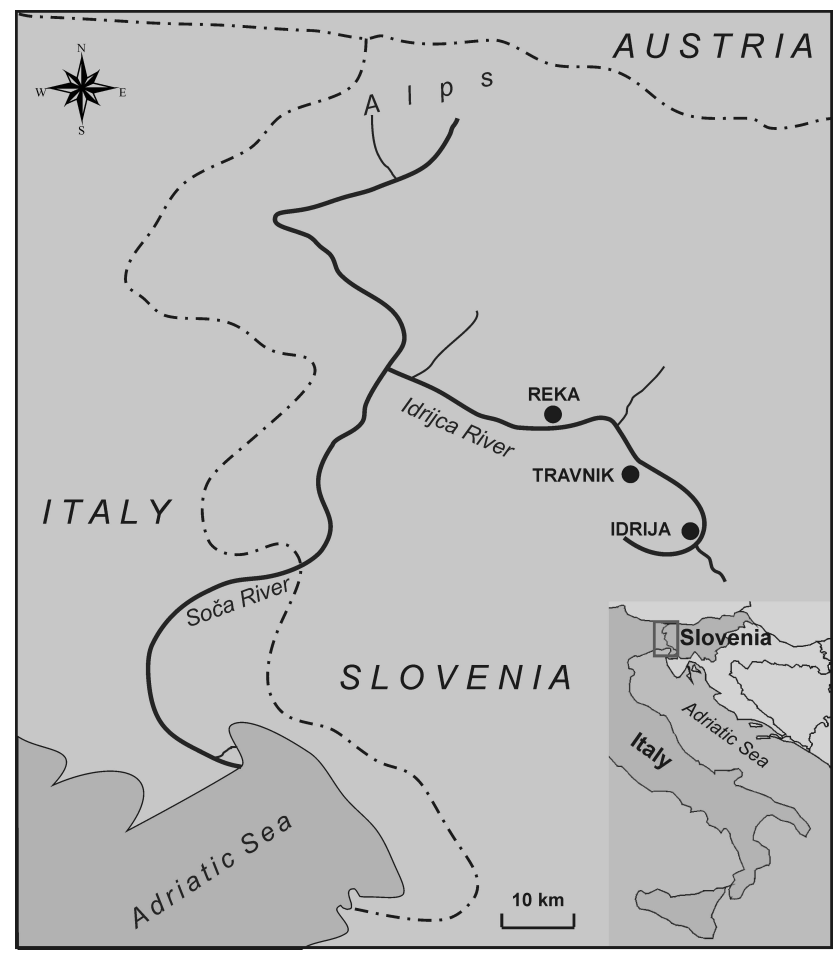

Fig. 1. Study area and sampling sites.

\section{Experimental}

\subsection{Field site and samples characteristics}

The world's second largest mercury deposit is located in the very narrow Idrijca Valley, in the town of Idrija (Fig. 1). Along the valley the River Idrijca flows through the town of Idrija and merges with the River Soča about $40 \mathrm{~km}$ downstream from Idrija. The whole area is geomorphologically very heterogeneous, with a wide range of altitudes from 170 to more than $2000 \mathrm{~m}$ a.s.l. Forests cover as much as $80 \%$ of the surface, while the remaining $20 \%$ is mostly natural grassland with some pastures. The study area has a warm humid temperate climate. The average air temperature for those months representative of the seasonal meteorological variation in the domain are $0-2{ }^{\circ} \mathrm{C}$ in January, $6-10^{\circ} \mathrm{C}$ in April, $16-22{ }^{\circ} \mathrm{C}$ in July, and $8-12{ }^{\circ} \mathrm{C}$ in October. Concerning precipitation, all seasons receive approximately the same amount with no distinctive dry or wet periods. As the mountains (Julian Alps) block air circulation from the northern Adriatic Sea in a northerly direction, annual precipitation here is very high and ranges between 2000 and $3200 \mathrm{~mm} \mathrm{y}^{-1}$. High peaks and steep mountain slopes prevent air circulation in the valleys. The most common winds in this area follow the geography of the Idrijca valley.

Altogether, seven soil samples were collected from three locations in the Idrijca River catchment (Fig. 1). Soil samples were selected with respect to total mercury concentration, 
land cover and soil texture. At each of the three locations (Idrija, Travnik and Reka) two types of soils, meadow and forest soil, respectively, were sampled. At the Travnik location soil sample from the alluvial plain was also obtained. During the LFMS experiment fresh non-homogenized soil samples were investigated together with the vegetation cover, representing the actual situation in the field. Therefore, approximately $1 \mathrm{~m}^{2}$ of the top $3 \mathrm{~cm}$ of soil sample (O horizon) was collected at each site by means of a PVC cutter. In order to characterize these samples, beside the total mercury concentrations, the texture and the organic matter content (OM) were determined as additional variables.

The total mercury concentrations of the samples investigated covered a range from 4 to $417 \mu \mathrm{gg}^{-1}$. As a result of deposition and accumulation of contaminated suspended particulate matter during high flow or flooding of the River Idrijca, the highest $\mathrm{THg}$ concentrations were measured in the alluvial plain soil from Travnik. In this study, samples were characterized for THg content only. However, it is known from previous studies performed at these locations, that soils closer to the pollution sources are relatively enriched with cinnabar, while at locations more distant from the pollution sources, soils are enriched in more mobile non-cinnabar mercury forms, more available for transformations (Biester et al., 2002; Gosar et al., 2006; Kocman et al., 2004). In terms of texture, samples can be divided into two groups. Meadow soil sample from the Idrija and both samples from Travnik location have a clayey texture, while forest soil from the Idrija, alluvial soil and soils from the Reka location have a loamy texture with a relatively equal mixture of sand and silt particles. Table 1 gives an overview of the sample characteristics.

\subsection{Laboratory flux measurement system (LFMS)}

For the determination of mercury fluxes from soil under controlled environmental conditions, a laboratory flux measurement system (LFMS) developed and designed by Bahalmann et al. (2006) was used. The LFMS is constructed of a cylindrical flux chamber with a diameter of $50 \mathrm{~cm}$ corresponding to a surface area of $\sim 2000 \mathrm{~cm}^{2}$ and a height of $40 \mathrm{~cm}$, resulting in a chamber volume of $80 \mathrm{~L}$. All system parts coming in contact with samples are made of or coated with Teflon. The bottom and the side of the chamber are made of Teflon coated stainless steel and the top is made of FEP-sheet $(0.25 \mathrm{~mm}$ thick). For continuous mixing of incoming air a fan is installed in the centre of the flux chamber. The use of the fan avoids stagnation zones and uncontrolled induction of vertical components of airflow. Ambient air is pulled through the chamber using high capacity mass flow controllers and membrane pumps. $\mathrm{Hg}$ is removed from the incoming ambient air by means of an activated carbon scrubber. To investigate the influence of solar radiation on mercury exchange processes, a solar simulator was used with a 2000W Xenon short arc lamp as a light source (referred as irradiation with UV light in this work). The Xenon arc lamp provides a continuous light spectrum with a constant intensity of $320 \mathrm{~W} \mathrm{~m}^{-2}$. The spectrum is quite similar to the AMO-0 spectrum in the visible UV region. About $65 \%$ of the outcoming IR-radiation was adsorbed by a water filter (thickness: $10 \mathrm{~cm}$ ). This significantly reduces the heating of the substrate. The temperature was continuously measured in the soil at $0.5 \mathrm{~cm}$ depth using a thermocouple thermometer. The soil temperature at $0.5 \mathrm{~cm}$ depth is referred to as SST-0.5 in this work. The concentrations of $\mathrm{Hg}$ were measured continuously at the outlet of the chamber by an RA-915 ${ }^{+}$Zeeman Mercury Analyzer. During the experiment, $\mathrm{Hg}$ concentrations were also sporadically measured at the inlet of the chamber (e.g. at the beginning and the end of the experiment, before the precipitation simulation...) in order to check the efficiency of $\mathrm{Hg}$ removal from the incoming air by activated carbon. As all $\mathrm{Hg}$ was removed from the incoming air, fluxes were then calculated using Eq. (1):

$\mathrm{MEF}=\frac{C_{o} Q}{A}$

where MEF is the mercury emission flux $\left(\mathrm{ng} \mathrm{m}^{-2} \mathrm{~h}^{-1}\right), C_{o}$ is the concentration $\left(\mathrm{ng} \mathrm{m}^{-3}\right)$ at the outlet, $Q$ is the flow rate through the chamber $\left(\mathrm{m}^{3} \mathrm{~h}^{-1}\right)$ and $A$ is the chamber surface area $\left(\mathrm{m}^{2}\right)$.

\subsubsection{Experimental set-up}

Based on the recommendations of the LFMS designer, the standard operating conditions chosen for the experiments were as follows: a flushing flow rate of $12 \mathrm{~L} \mathrm{~min}^{-1}$, a fan voltage of $6 \mathrm{~V}$, a soil surface temperature of $20-25^{\circ} \mathrm{C}$, a soil layer of $3 \mathrm{~cm}$ thickness and no light exposure (Bahlmann et al., 2006). Simultaneous measurements of $\mathrm{Hg}^{0}$ were made at the outlet of the chamber using an RA-915+ Lumex Zeeman portable mercury spectrometer (Sholupov and Ganeyev, 1995). This system utilized atomic absorption in a column of chamber air which was constantly replenished by the pump maintaining an air flow of $12 \mathrm{~L} \mathrm{~min}^{-1}$ through the system. By using Zeeman modulation techniques the system is particularly sensitive and real time measurements can be performed rather than relying on the customary gold amalgamation technique for pre-concentration before atomic absorption spectrometer measurements. Spectra were collected and recorded by a computer as $10 \mathrm{~s}$ averages. The baseline correction time (period of time during which the level corresponding to a zero mercury vapour concentration in the analytical cell) was set to be $20 \mathrm{~s}$ and was measured every 5 min. The calibration and function of the instrument was checked prior to every measurement by measuring a known $\mathrm{Hg}$ vapour concentration in the test cell installed in the instrument. The relative deviation of the measured value of the $\mathrm{Hg}$ vapor concentration in the test cell from the tabulated value was within $5 \%$. The calculated detection limits of the RA$915^{+}$Zeeman Mercury Analyzer ranged between 0.5 and 
Table 1. Characteristics of the samples investigated.

\begin{tabular}{lllllll}
\hline Location & Sample & $\begin{array}{l}\text { Distance from } \\
\text { the mine }(\mathrm{km})\end{array}$ & $\begin{array}{l}\text { Type/ } \\
\text { Land cover }\end{array}$ & Texture & $\begin{array}{l}\text { OM } \\
(\%)\end{array}$ & $\begin{array}{l}\text { THg } \\
\left(\mu \mathrm{g} \mathrm{g}^{-1}\right)\end{array}$ \\
\hline Idrija & $\mathrm{I}-1$ & 0.5 & forest & loamy & 16 & $251 \pm 4.2$ \\
Idrija & $\mathrm{I}-2$ & 0.5 & meadow & clayey & 10 & $100 \pm 2.2$ \\
Travnik & $\mathrm{T}-1$ & 15 & forest & clayey & 22 & $19.2 \pm 0.4$ \\
Travnik & T-2 & 15 & meadow & clayey & 18 & $23.4 \pm 0.7$ \\
Travnik & T-3 & 15 & alluvial plain & loamy & 8 & $417 \pm 78$ \\
Reka & R-1 & 25 & forest & loamy & 19 & $9.2 \pm 0.6$ \\
Reka & R-2 & 25 & meadow & loamy & 16 & $4.1 \pm 0.1$ \\
\hline
\end{tabular}

$1.0 \mathrm{ng} \mathrm{m}^{-3}$. Under the described experimental conditions, this corresponds to the mercury flux of $1.8-3.6 \mathrm{ng} \mathrm{m}^{-2} \mathrm{~h}^{-1}$.

\subsubsection{Sample processing}

The influence of soil surface temperature, soil moisture and radiation was investigated by varying the parameter of interest and determining the response of the mercury emission flux (MEF) while all other parameters were kept constant. Altogether, mercury emission fluxes were measured over each sample for $8-16 \mathrm{~h}$. At the beginning of the experiment, to investigate the temperature effect, samples were cooled down to about $-2{ }^{\circ} \mathrm{C}$ and then allowed to warm up to room temperature. Simultaneously, the mercury emission flux and soil surface temperature were measured. When the fluxes and soil temperature became constant (after approx. $6 \mathrm{~h})$ samples were irradiated with an UV light of a constant intensity $\left(320 \mathrm{~W} \mathrm{~m}^{-2}\right)$ for $1 \mathrm{~h}$. After $1 \mathrm{~h}$, the UV light was turned off and MEF was measured until the levels before the irradiation were achieved, which took approximately one hour. The samples were then left overnight at room temperature without the air flow flushing through the system. Next day, before the measurements continued, the air flow was renewed through the system and the fan was turned on for about half hour to avoid stagnation zones and uncontrolled induction of vertical components of the airflow. Mercury fluxes were then measured under standard conditions. After approx. $2 \mathrm{~h}$, precipitation was simulated by rewetting the sample using $300 \mathrm{~mL}$ of Milli-Q water. The amount of water used corresponds to a $1.5 \mathrm{~mm}$ precipitation event. Later on, when the fluxes became constant (usually within the next $4 \mathrm{~h}$ ) the samples were irradiated for an additional hour. The moisture content was measured in the uppermost $5 \mathrm{~mm}$ of the sample. An aliquot of the sample was obtained and its moisture measured two times during the experiment for each sample: after the samples reached room temperature and fluxes became constant and just before the precipitation simulation. Each of the seven samples was processed once during the LFMS experiment. Before processing a new sample, flux chamber blanks were measured under dark and light conditions and were below the detection limit.

\subsection{Additional analyses}

The $\mathrm{Hg}$ content of soil samples from each flux measurement site was determined after acidic decomposition with nitric, perchloric and sulphuric acid at $250^{\circ} \mathrm{C}$ by an LCD Milton Roy CV AAS mercury analyzer (Horvat et al., 1991). Quality control included reagent blanks to assess contamination and replicate samples to check precision. In order to match the concentrations and matrix requirements three reference materials were used to assess accuracy: CRM BCR 580, Estuarine sediment, obtained from the Institute for Reference Materials and Measurements (IRMM), RM IAEA 405, Trace elements and methylmercury in estuarine sediment, obtained from the International Atomic Energy Agency (IAEA) and SOIL-1, laboratory reference material obtained from the Idrija region (Kocman et al., 2006). The limit of detection (LOD) and limit of quantification (LOQ) were $0.5 \mu \mathrm{g} \mathrm{kg}^{-1}$ and $1 \mu \mathrm{g} \mathrm{kg}^{-1}$, respectively. The reproducibility of the method was $3 \%$ to $5 \%$. Total soil organic matter (OM) was estimated by loss-on-ignition procedure (Heiri et al., 2001). Soil texture was determined based on a simple feel test according to the FAO guidelines (FAO, 2006).

\section{Results and discussion}

Results of the LFMS experiment are graphically presented in Fig. 2. Time values marked on the $\mathrm{x}$ axis correspond to the effective experimental time in hours. In general, with the exception of the two samples collected at the Reka site (R-1 and R-2), similar trends were observed for all samples under investigation. The strong influence of all three parameters investigated, namely soil surface temperature, radiation and soil moisture, on the momentum MEF was observed. During sample processing by regulating various parameters, a wide range of MEFs was measured from less than 2 to $530 \mathrm{ng} \mathrm{m}^{-2} \mathrm{~h}^{-1}$. These MEF values significantly exceed those reported for unaltered or background sites (Zhang et al., 2001; Nacht and Gustin, 2004) and are comparable to those measured worldwide in areas of $\mathrm{Hg}$ mine waste and 

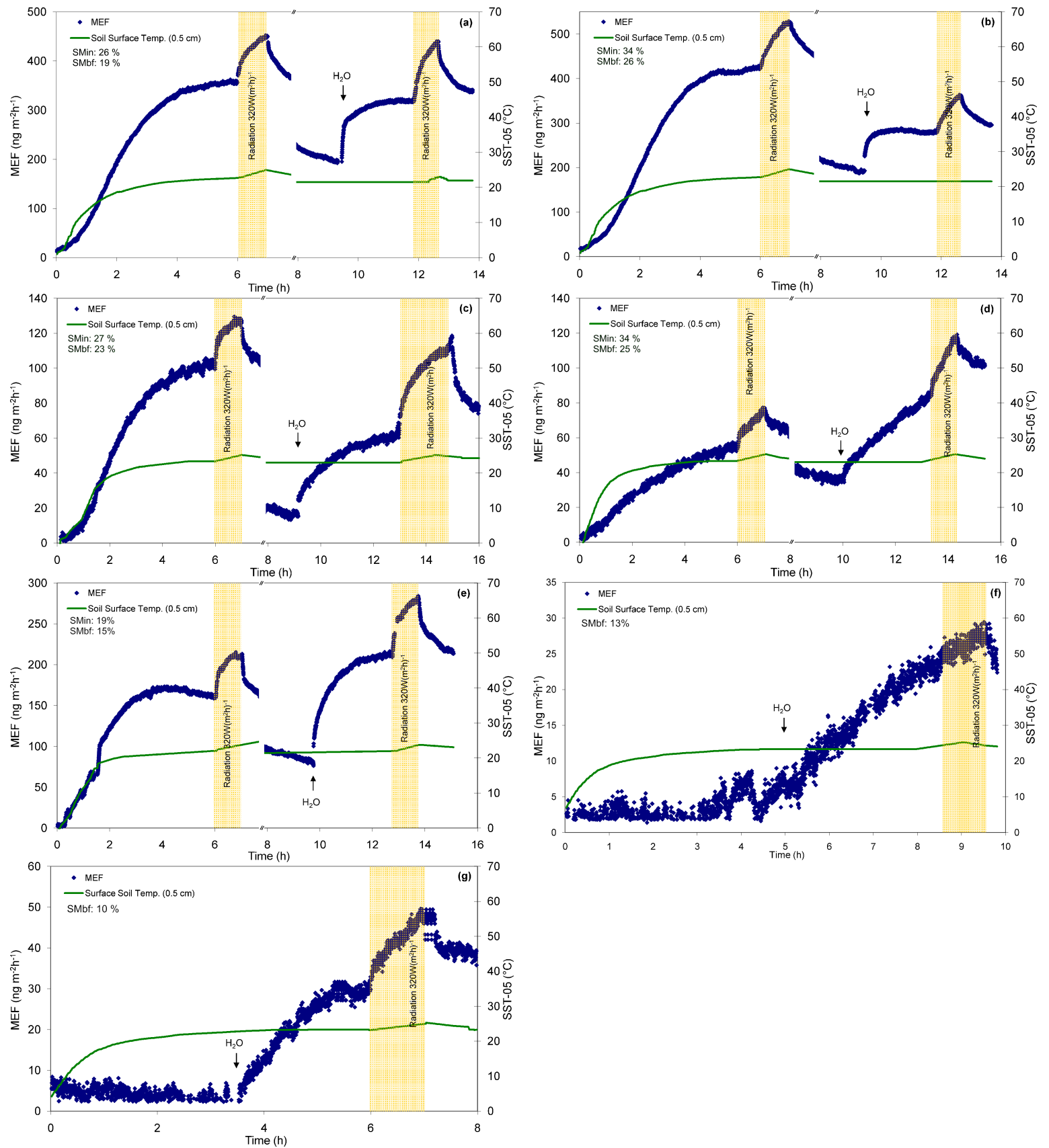

Fig. 2. Mercury emission flux (MEF) measured under different simulated conditions (temperature, precipitation and UV light induced). (a) I-1, (b) I-2, (c) T-1, (d) T-2, (e) T-3, (f) R-1, (g) R-2.

areas disturbed by mining (Ferrara et al., 1998b; Gustin et al., 2002; Wang et al., 2005). A significant spatial heterogeneity of MEFs was observed and the overall fluxes corresponded well to the total mercury concentration in the soils. Hence, with the exception of the alluvial soil sample (T-3), the highest MEFs were measured from samples obtained in the vicinity of the mining district in the town of Idrija. A clear and significant decrease of MEFs was then observed with increasing distance from these sites. However, it must be noted that the values reported here are of informative nature only, as the use of cleaned air in the experimental set-up could impact the magnitude of measured fluxes.

\subsection{Effect of soil temperature}

The effect of soil temperature on MEF was investigated in the temperature range between 0 and $25^{\circ} \mathrm{C}$. Temperature was measured at the depth of $5 \mathrm{~mm}$. Following the observations 
presented by Carpi and Lindberg (1998), this is the soil layer thickness in which reduction of non-volatile $\mathrm{Hg}$ species to volatile ones occurs. For samples collected at the Idrija and Travnik sites, a strong positive correlation between the soil surface temperature and the MEF with correlation coefficients between 0.80 and 0.85 was observed. Due to very low initial soil moisture content, as discussed in more detail in Sect. 3.3, the two samples from the Reka site produced different results compared to other samples. For all samples at temperatures below $0{ }^{\circ} \mathrm{C}$ no mercury flux was measured or the fluxes were below the limit of detection $\left(1.8 \mathrm{ng} \mathrm{m}^{-2} \mathrm{~h}^{-1}\right)$. This thermally controlled emission of mercury from soils depends on the equilibrium of $\mathrm{Hg}^{0}$ between the soil matrix and the soil gas. As suggested by Schlüter (2000), due to increasing thermal motion, the vapour pressure of highly volatile $\mathrm{Hg}^{0}$ is increased and sorption by soil is decreased. Moreover, increased temperature also causes an increase in reaction rates and microbiological activity, resulting in more intensive formation of volatile mercury species (Schlüter, 2000). Similar temperature affects as observed in our study were reported by other authors (Bahlmann et al., 2006; Zhang et al., 2001; Gillis and Miller, 2000; Carpi and Lindberg, 1998).

One way to understand the processes driving thermally enhanced emission is to calculate the activation energy associated with the $\mathrm{Hg}$ flux. The activation energy $(E a)$ is the energy which the system must absorb in order to initiate a $\mathrm{Hg}$ flux increase, or $\mathrm{Hg}$ emission, or release from soils to occur (Gustin et al., 2003). Assuming that the transfer of $\mathrm{Hg}^{0}$ from soil to atmosphere is governed by a pseudo first order reaction, the temperature dependence of $\mathrm{Hg}$ fluxes over the soil surface can be described by the Arrhenius equation and $E a$ can be directly calculated from the temperature dependence of the MEF:

$$
\operatorname{Ln}(\mathrm{MEF})=\operatorname{Ln}(A)-\frac{E_{a}}{R T}
$$

where $E a$ is the apparent activation energy, $A$ is the frequency factor, $T$ is the absolute temperature and $R$ is the gas constant. The concept of the apparent $E a$ refers to a thermally controlled reaction. Therefore, all experiments carried out under light conditions and simulated precipitation were excluded from the determination of $E a$. By fitting the Arrhenius equation to the data for MEFs at different soil temperatures, values of $E a$ for the soils investigated were calculated in the $82-109 \mathrm{~kJ} \mathrm{~mol}^{-1}$ range. These activation energies are in a good agreement with published data for mercury contaminated sites where $\mathrm{HgS}$ is the predominant mercury form (Lindberg et al., 1995) and are somewhat higher than values reported for background soils (Gustin et al., 1997; Bahlmann et al., 2006; Poissant and Casimir, 1998). Since the enthalpy of vaporization of elemental $\mathrm{Hg}$ is much lower $\left(59 \mathrm{~kJ} \mathrm{~mol}^{-1}\right)$ than the measured $\mathrm{Ea}$, it is evident that $\mathrm{Hg}$ emissions from soils cannot be solely explained by the direct emission of elemental $\mathrm{Hg}$ from the soil surface. Significantly higher $E a$ values were obtained for mercury contaminated soils from

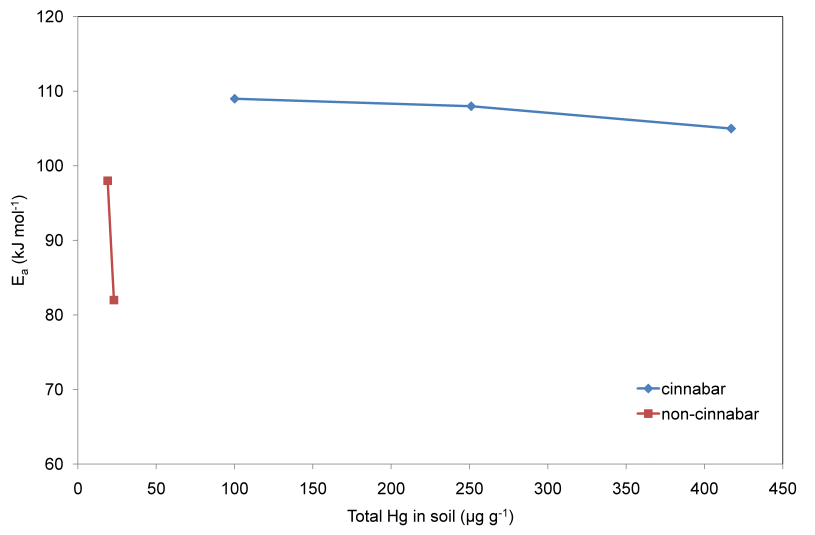

Fig. 3. Relation between the apparent activation energy $(E a)$ of MEFs and total mercury concentration in soils.

the Idrija location (108 and $109 \mathrm{~kJ} \mathrm{~mol}^{-1}$ ) and alluvial soil $\left(105 \mathrm{~kJ} \mathrm{~mol}^{-1}\right)$ compared to less contaminated samples from the Travnik location $\left(82\right.$ and $\left.98 \mathrm{~kJ} \mathrm{~mol}^{-1}\right)$. These results indicate the importance of not only the amount but also the type of mercury species and their binding in soils. It is known that increasing availability of mercury in soils to abiotic and biotic processes would increase the formation of volatile mercury species. As reported by Schlüter (2000), mercury evaporation occurs most easily in soils rich in $\mathrm{Hg}^{0}$, followed by soils dominated by inorganic $\mathrm{Hg}^{2+}$, which is bound to soil components and probably relatively easily available for transformation to volatile mercury species. The highest activation energy of mercury evaporation is usually needed for soils whose mercury content is dominated by $\mathrm{HgS}$, which is extremely insoluble, and therefore relatively unavailable for transformation (Schlüter, 2000). Consistent with this, the highest activation energies of mercury evaporation were calculated for Idrija (I-1 and I-2) and alluvial soil samples (T-3) whose mercury content is dominated by the extremely insoluble HgS (Kocman et al., 2006; Kocman et al., 2004), while the dominance of more easily available $\mathrm{Hg}^{2+}$ bound to soils at the Travnik sampling site (T-1 and T-2), as shown by Gosar et al. (2006), resulted in lower activation energies. When the $E a$ values obtained were plotted as a function of total mercury (THg) in soil, a decreasing trend of $E a$ with increasing THg concentration was observed for the two individual groups of samples (relatively enriched in cinnabar and in non-cinnabar Hg forms, respectively) (Fig. 3). This trend is more pronounced for the samples with lower $\mathrm{THg}$ concentration, which is in agreement with previously published results (Bahlmann et al., 2006) and further supports the hypothesis that the emission of mercury is controlled by pool of mercury available for reduction and desorption. 


\subsection{Effect of solar radiation}

With the exception of samples from the Reka location, during the LFMS experiment soils were irradiated twice for $1 \mathrm{~h}$ with UV light of a constant intensity $\left(320 \mathrm{~W} \mathrm{~m}^{-2}\right)$. The first irradiation was performed after approximately $6 \mathrm{~h}$ of when the samples reached room temperature and the second $3-4 \mathrm{~h}$ after simulated precipitation (Fig. 2). For all samples, an immediate steep and constant increase of MEF was observed during the irradiation. Within $1 \mathrm{~h}$, MEFs increased by $25-$ $65 \%$ compared to fluxes obtained under dark conditions. After the end of the radiation phase, a steep decrease of MEF followed and fluxes became more constant within the next hour, revealing a similar, though opposite trend as during irradiation. For samples I-2, T-2 and T-3 a comparable increase was observed during both irradiation phases, while for two forest samples (I-1 and T-1), somewhat higher light-induced offset was observed after simulated precipitation. Moreover, one hour after the irradiation of wetted samples, MEFs remained up to $22 \%$ higher compared to values before the irradiation phase. These observations are in agreement with the results of Bahlmann et al. (2006) who showed that the lightinduced flux over wet soils has a significantly longer effect compared to light-induced flux over dry soils. This effect was found to be more pronounced for samples with more abundant soluble $\mathrm{Hg}$ species (T-1 and T-2) compared to samples where sulfide species are dominant (I-1, I-2 and T-3), indicating the influence of mercury speciation in soils on the MEF, as reported before (Gustin et al., 2002). These observations would then suggest that the pool of mercury available for light-induced emission is more easily recharged by the aqueous phase when more soluble $\mathrm{Hg}$ species are present. This can then also explain the absence of a correlation between the light-induced offset and the total mercury concentrations measured in these samples. Overall, these results revealed clear evidence that the light-induced flux depends on both the soil moisture level and the form of $\mathrm{Hg}$ present in soil.

One of the reasons for the elevated MEFs could also be temperature which increased and remain elevated by 1 to $2{ }^{\circ} \mathrm{C}$ during the $1 \mathrm{~h}$ irradiation in the upper $0.5 \mathrm{~cm}$ soil layer. To check this effect, measured fluxes under light irradiation were compared to the calculated fluxes using the temperature dependence of MEF obtained under the dark phases of the experiments (Eq. 2). The modelled fluxes underestimated the measured fluxes during irradiation phases by $14-76 \%$. Hence, the observed increase of the soil surface temperature during the radiation only accounts for part of the observed MEF increase. These results show that the light-induced flux is independent of the soil temperature and reveal evidence of photolytical reduction of divalent mercury species at the soil surface, as previously reported by others (Carpi and Lindberg, 1998; Gillis and Miller, 2000; Zhang et al., 2001; Gustin et al., 2002). It must be noted, however, that although high, the observed light-induced offset was much smaller than reported by other authors. This might be due to the fact that others measured fluxes over bare soil, while in this study MEFs measured over soil overgrown with a vegetation cover are reported. Obviously, a part of the energy induced by the radiation is absorbed by the vegetation cover. As suggested by Choi and Holsen (2009), Hg emission from soils is partly limited by the vegetation which helps to maintain relatively high soil moisture and limits the amount of heat and solar radiation reaching the soil surface. However, it must be noted that during the experiment, irradiation was stopped before the light-induced offset became constant and reached its maximum.

\subsection{Effect of soil moisture}

Soil moisture was already identified as one of the key parameters affecting the MEF from soils (Xin et al., 2007; Carpi and Lindberg, 1997, 1998; Gillis and Miller, 2000). In this study, its effect was investigated by following the change in soil moisture content during the experiment, as well as by simulation of precipitation. Soil moisture content was measured two times during the experiment: after the samples reached room temperature (referred as initial moisture, $\mathrm{SM}_{i n}$ ) and just before the precipitation simulation the next day $\left(\mathrm{SM}_{b f}\right)$. The initial soil moisture differed significantly from sample to sample and ranged between 10 and $34 \%$ (Fig. 2).

With the exception of samples from the Reka location samples were processed in two phases within two days. Approximately one hour after the first UV irradiation phase, the experiment was stopped and samples left in dark at room temperature. After 10-12 $\mathrm{h}$ when samples were further investigated, a significant decrease of MEFs was observed. MEFs measured under standard operating conditions became 1.52.3 fold lower (Fig. 2). Two possible explanations for these observations are suggested. The observed decrease could be explained by the change of soil surface moisture which decreased between 4 and 9\% during this time (Fig. 2). Consistent with this assumption, there is a good agreement between the magnitude of the MEF decrease and the change of surface soil moisture for individual samples. On the other hand, it is known that the MEF over soils can be in a large part controlled by soil moisture tension, not only by the soil moisture level (Bahlmann et al., 2004). After defrosting when the samples reached room temperature, soil water started to percolate through the soil column. Consequently, the soil moisture tension in the surface layer became weaker, resulting in less $\mathrm{Hg}$ enriched soil air being displaced and less $\mathrm{Hg}$ being desorbed from the soil surface. Moreover, it must be noted that under the experimental conditions a rather rapid decrease of both soil moisture and soil moisture tension was enhanced by a fan installed for continuous mixing of incoming air in the flux chamber, which is not the case under natural conditions.

Rewetting of soils (precipitation simulation) resulted in a sharp and rapid spike of the MEFs for all samples. MEFs 
increased 1-3 fold within the first 20 min. This sharp spike immediately after the simulated precipitation can be explained by physical displacement of interstitial soil air by the infiltrating water. It is assumed that the more polar water molecules successfully displace $\mathrm{Hg}$ from binding sites on the soil, facilitating its release (Gustin, 2003). After the initial spike, fluxes slowly increased until they became rather constant within the next 3-4h. However, significant differences between the investigated samples were observed. E.g., although very deficient in terms of total $\mathrm{Hg}$ concentrations compared to other samples, two samples collected at the Reka site (R-1 and R-2) revealed the strongest response to simulated precipitation. At the same time, these are the samples with the lowest initial soil moisture content (Fig. 2). Moreover, the MEF measured from these two samples before rewetting under standard operating conditions were close to the LOD and no correlation with the soil temperature was observed. These results, and a knowledge of the very varied meteorological conditions at different sampling sites during sampling, suggest that the flux of $\mathrm{Hg}^{0}$ from soil is a function not only of the precipitation but also of the soil moisture content prior to the precipitation event. To further investigate this assumption, the surface soil moistures before a precipitation simulation and the enhancement of the MEF due to the precipitation were correlated using a precipitation enhancement factor $(f)$ defined as:

$f=\frac{\mathrm{MEF}_{a f t}-\mathrm{MEF}_{b f}}{\mathrm{MEF}_{b f}}$

where $\mathrm{MEF}_{\text {aft }}$ is the mercury flux value calculated for the 20 min period immediately after the simulated precipitation and $\mathrm{MEF}_{b f}$ is the mercury flux value determined just before the simulated precipitation (Song and Van Heyst, 2005). A plot of the resulting precipitation enhancement factors versus the surface soil moisture before the rain event $\left(S M_{b f}\right)$ is given is Fig. 4 . The figure clearly indicates a declining trend in the precipitation enhancement factor with increasing surface soil moisture. The data thus indicate that the enhancement of the $\mathrm{Hg}$ flux after a precipitation event is much lower if the surface soil moisture is greater than approximately $15 \%$, which is in a good agreement with previous observations (Song and Van Heyst, 2005).

These results revealed clear evidence that the MEF from soil is connected to the mercury in the aqueous soil phase. In soils, inorganic divalent $\mathrm{Hg}$ is the dominat mercury form. Hence, before being emitted, $\mathrm{Hg}$ in soil must dissolve from soil particles into the soil aqueous phase and subsequently be reduced to $\mathrm{Hg}^{0}$ in solution (Lindberg et al., 1999). These processes are influenced by the mobility of mercury in the soil. In this study, the mobility of mercury was not investigated. However, it is known from $\mathrm{Hg}$ fractionation studies performed on soils from the Idrija region that water soluble $\mathrm{Hg}$ correlates positively with the non-cinnabar $\mathrm{Hg}$ fractions in these soils (Kocman et al., 2004). Consistent with this, a significantly higher relative increase of MEFs was observed

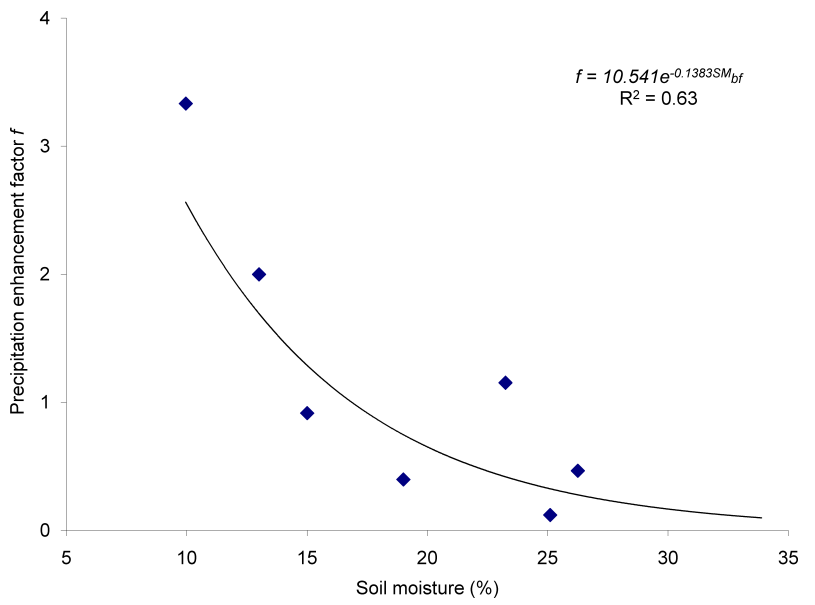

Fig. 4. Precipitation enhancement factor versus surface soil moisture before a simulated precipitation.

after simulated precipitation for samples where more mobile $\mathrm{Hg}$ fractions are dominant (Reka and Tavnik locations), compared to samples from Idrija where insoluble cinnabar prevails.

\subsection{Temporal stability of MEF}

Due to its moderate total $\mathrm{Hg}$ concentration $\left(19 \mu \mathrm{g} \mathrm{g}^{-1}\right)$ compared to other samples, a forest soil sample from location Travnik (T-1) was chosen and temporal stability of its MEF was investigated. Under the defined standard conditions the observed MEF was $54 \mathrm{ng} \mathrm{m}^{-2} \mathrm{~h}^{-1}$ and remained constant within $\pm 15 \%$ for the next $100 \mathrm{~h}$. This temporal stability under constant environmental conditions indicates that a constant amount of mercury must be available for volatilization. Thus, the stability of fluxes over time also depends on the amount of mercury available for vaporization. When assuming that the volatile fraction consists primarily of $\mathrm{Hg}^{0}$, the permanence of the fluxes can be estimated based on the amount of $\mathrm{Hg}^{0}$ in soil and the actual measured flux. However, there is no direct reference method and/or appropriate reference materials for measurements of the volatile mercury fraction in soils. Hence, the available pool of volatile mercury in soil is difficult to determine. Some efforts have been made before to determine the volatile mercury pool in soils from the Idrija region by applying a simple $\mathrm{Hg}$ volatilization simulation experiment during which samples were heated to $70^{\circ} \mathrm{C}$ for several hours. The procedure together with the results of the volatilization simulation experiment was described into more detail in Kocman et al. (2004). Taking the results of that study into account, the total amount of $\mathrm{Hg}^{0}$ per $\mathrm{m}^{2}$ and $\mathrm{cm}$ at the Idrija forest site (I-1) is approximately $300 \mu \mathrm{g}$ when assuming a soil density of $1.5 \mathrm{~g} \mathrm{~cm}^{-3}$. This is about $1 \times 10^{3}$ times higher than the observed flux of $150 \mathrm{ng} \mathrm{m}^{-2} \mathrm{~h}^{-1}$ at $20^{\circ} \mathrm{C}$ and thus could theoretically maintain this flux for more than a year. However, it should be 
noted that in this calculation processes such as $\mathrm{Hg}$ atmospheric deposition, as well as the fact that the pool of $\mathrm{Hg}$ in soil available for volatilization can be significantly enhanced by increase of soil moisture, temperature and solar radiation, were not taken into account. Moreover, the yearly average temperatures in the Idrija region are much lower than $20^{\circ} \mathrm{C}$.

\subsection{Potential application of the LFMS experiment}

In order to understand the significance as well as the environmental impacts of $\mathrm{Hg}$ emissions from contaminated sites such as Idrija region, spatially limited measured fluxes must be scaled to larger areas. Consideration must be given to the magnitude of the emissions and their longevity. Due to the complex mechanisms affecting this process, this can be a difficult task. The results of this study will help to predict mercury emissions to the atmosphere from contaminated surfaces in the Idrija region. Site specific empirical correlations between the $\mathrm{Hg}$ emission fluxes measured and the parameters controlling this process will be incorporated in the mercury emission model developed within the geographic information system (GIS). In this way, spatial distribution and significance of most polluted sites that need to be properly managed will be assessed.

\section{Conclusions}

The measurements presented here represent the first systematic observations of mercury emission from soils in the Idrija $\mathrm{Hg}$-mine region. The data provide new insights into the kinetics of mercury surface-atmosphere exchange, with a special focus on contaminated sites. The results show that the emission of mercury from soils is mainly driven by a thermal and an additional light-induced mechanism, while the soil aqueous phase seems to be responsible for recharging the pool of mercury in the soil available for both the lightand thermally-induced flux. Moreover, the results indicated the importance of not only the amount but also the type of mercury species and their binding in soils. $\mathrm{Hg}$ emission was found to occur more easily from sites where more mobile $\mathrm{Hg}$ forms are dominant, compared to sites where insoluble cinnabar prevails. Considering the very high total $\mathrm{Hg}$ concentrations and the high temporal stability of MEF it is likely that mercury emission from mercury-contaminated soils in the Idrija region will remain a significant contributor to the atmospheric load of mercury for years to come, especially if the land use and/or the remediation actions are not managed properly.

Acknowledgements. The authors acknowledge financial support from the state budget by the Slovenian Research Agency and the research group "Cycling of nutrients and contaminants in the environment, mass balances and modeling environmental processes and risk analysis" (P1-0143). Special thanks are given to E. Bahlmann and R. Ebinghaus for their help with the LFMS system.
Authors also thank A. Byrne for linguistic corrections.

Edited by: N. Pirrone

\section{References}

Bahlmann, E., Ebinghaus, R., and Ruck, W.: The effect of soil moisture on the emissions of mercury from soils, RMZ - Mater. Geoenviron., 51, 791-794, 2004.

Bahlmann, E., Ebinghaus, R., and Ruck, W.: Development and application of a laboratory flux measurement system (LFMS) for the investigation of the kinetics of mercury emissions from soils, J. Environ. Manage., 81, 114-125, 2006.

Bergan, T. and Rodhe, H.: Oxidation of elemental mercury in the atmosphere; constraints imposed by global scale modelling, J. Atmos. Chem., 40, 191-212, 2001.

Biester, H., Müller, G., and Schöler, H. F.: Binding and mobility of mercury in soils contaminated by emissions from chlor-alkali plants, Sci. Total Environ., 284, 191-203, 2002.

Carpi, A. and Lindberg, S. E.: Sunlight-mediated emission of elemental mercury from soil amended with municipal sewage sludge, Environ. Sci. Technol., 31, 2085-2091, 1997.

Carpi, A. and Lindberg, S. E.: Application of a teflon dynamic flux chamber for quantifying soil mercury flux: Tests and results over background soil, Atmos. Environ., 32, 873-882, 1998.

Choi, H.-D. and Holsen, T. M.: Gaseous mercury emissions from unsterilized and sterilized soils: The effect of temperature and UV radiation, Environ. Pollut., 157, 1673-1678, 2009.

Coolbaugh, M., Gustin, Gustin, M., Rytuba, and Rytuba, J.: Annual emissions of mercury to the atmosphere from natural sources in Nevada and California, Environ. Geol., 42, 338-349, 2002.

Engle, M. A., Gustin, M. S., and Zhang, H.: Quantifying natural source mercury emissions from the Ivanhoe mining district, north-central Nevada, USA, Atmos. Environ., 35, 3987-3997, 2001.

FAO: Guidelines for Soil Description, 4th ed., FAO, Rome, Italy, 95 pp., 2006.

Feng, X., Wang, S, Qiu, G., Hou, Y., and Tang, S.: Total gaseous mercury emissions from soil in Guiyang, Guyizhou, China, J. Geophys. Res., 110, D14306, doi:10.1029/2004JD005643, 2005.

Ferrara, R., Maserti, B. E., Andersson, M., Edner, H., Ragnarson, P., Svanberg, S., and Hernandez, A.: Atmospheric mercury concentrations and fluxes in the Almadén district (Spain), Atmos. Environ., 32, 3897-3904, 1998a.

Ferrara, R., Mazzolai, B., Edner, H., Svanberg, S., and Wallinder, E.: Atmospheric mercury sources in the Mt. Amiata area, Italy, Sci. Total Environ., 213, 13-23, 1998b.

Gillis, A. A. and Miller, D. R.: Some local environmental effects on mercury emission and absorption at a soil surface, Sci. Total Environ., 260, 191-200, 2000.

Gosar, M., Šajn, R., and Biester, H.: Binding of mercury in soils and attic dust in the Idrija mercury mine area (Slovenia), Sci. Total Environ., 369, 150-162, 2006.

Grönlund, R., Edner, H., Svanberg, S., Kotnik, J., and Horvat, M.: Mercury emissions from the Idrija mercury mine measured by differential absorption lidar techniques and a point monitoring absorption spectrometer, Atmos. Environ., 39, 4067-4074, 2005.

Gustin, M. S., Taylor, G. E., Leonard, T. L., and Keislar, R. E.: Atmospheric mercury concentrations associated with geologically 
and anthropogenically enriched sites in central western Nevada, Environ. Sci. Technol., 30, 2572-2579, 1996.

Gustin, M. S., Taylor Jr., G. E., and Maxey, R. A.: Effect of temperature and air movement on the flux of elemental mercury from substrate to the atmosphere, J. Geophys. Res., 102, 3891-3898, 1997.

Gustin, M. S., Lindberg, S. E., Austin, K., Coolbaugh, M., Vette, A., and Zhang, H.: Assessing the contribution of natural sources to regional atmospheric mercury budgets, Sci. Total Environ., 259, 61-71, 2000.

Gustin, M. S., Biester, H., and Kim, C. S.: Investigation of the light-enhanced emission of mercury from naturally enriched substrates, Atmos. Environ., 36, 3241-3254, 2002.

Gustin, M. S.: Are mercury emissions from geologic sources significant? A status report, Sci. Total Environ., 304, 153-167, 2003.

Gustin, S., Coolbaugh, M., Engle, M., Fitzgerald, B., Keislar, R., Lindberg, S., Nacht, D., Quashnick, J., , Rytuba, J., Sladek, C., Zhang, H., and Zehner, R.: Atmospheric mercury emissions from mine wastes and surrounding geologically enriched terrains, Environ. Geol., 43, 339-351, 2003.

Heiri, O., Lotter, A. F., and Lemcke, G.: Loss on ignition as method for estimating organic and carbonate content in sediments: reproducibility and comparability of results. J. Paleolim. 25, 101-110, 2001.

Hines, M. E., Faganeli, J., Adatto, I., and Horvat, M.: Microbial mercury transformations in marine, estuarine and freshwater sediment downstream of the Idrija mercury mine, Slovenia, Appl. Geochem., 21, 1924-1939, 2006.

Horvat, M., Lupšina, V., and Pihlar, B.: Determination of total mercury in coal fly ash by gold amalgamation cold vapour atomic absorption spectrometry, Anal. Chim. Acta, 24, 71-79, 1991.

Horvat, M., Jereb, V., Fajon, V., Logar, M., Kotnik, J., Faganeli, J., Hines, M. E., and Bonzongo, J. C.: Mercury distribution in water, sediment and soil in the Idrijca and Soča river systems, Geochem-explor. Environ. Anal., 2, 287-296, 2002.

Kocman, D., Horvat, M., and Kotnik, J.: Mercury fractionation in contaminated soils from the Idrija mercury mine region, J. Environ. Monitor., 6, 696-703, 2004.

Kocman, D., Bloom, N. S., Akagi, H., Telmer, K., Hylander, L., Fajon, V., Jereb, V., Jacimovic, R., Smodiš, B., Ikingura, J. R., and Horvat, M.: Preparation and characterization of a soil reference material from a mercury contaminated site for comparability studies, J. Environ. Manage., 81, 146-154, 2006.

Kotnik, J., Horvat, M., and Dizdarevič, T.: Current and past mercury distribution in air over the Idrija $\mathrm{Hg}$ mine region, Slovenia, Atmos. Environ., 39, 7570-7579, 2005.

Lin, C.-J. and Pehkonen, S. O.: The chemistry of atmospheric mercury: A review, Atmos. Environ., 33, 2067-2079, 1999.

Lindberg, S. E., Kim, K.-H., Meyers, T. P., and Owens, J. G.: Micrometeorological gradient approach for quantifying air/surface exchange of mercury vapor: Tests over contaminated soils, Environ. Sci. Technol., 29, 126-135, 1995.

Lindberg, S. E., Zhang, H., Gustin, M., Vette, A., Marsik, F., Owens, J., Casimir, A., Ebinghaus, R., Edwards, G., Fitzgerald, C., Kemp, J., Kock, H. H., London, J., Majewski, M., Poissant, L., Pilote, M., Rasmussen, P., Schaedlich, F., Schneeberger, D., Sommar, J., Turner, R., Wallschleger, D., and Xiao, Z.: Increases in mercury emissions from desert soils in response to rainfall and irrigation, J. Geophys. Res., 104, 21879-21888, 1999.
Mason, R. P., Fitzgerald, W. F., and Morel, F. M. M.: The biogeochemical cycling of elemental mercury: Anthropogenic influences, Geochim. Cosmochim. Ac., 58, 3191-3198, 1994.

Nacht, D. M. and Gustin, M. S.: Mercury emissions from background and altered geologic units throughout Nevada, Water Air Soil Poll., 151, 179-193, 2004.

Nacht, D. M., Gustin, M. S., Engle, M. A., Zehner, R. E., and Giglini, A. D.: Atmospheric mercury emissions and speciation at the Sulphur bank mercury mine superfund site, northern California, Environ. Sci. Technol., 38, 1977-1983, 2004.

Pirrone, N., Cinnirella, S., Feng, X., Finkelman, R. B., Friedli, H. R., Leaner, J., Mason, R., Mukherjee, A. B., Stracher, G., Streets, D. G., and Telmer, K.: Global mercury emissions to the atmosphere from natural and anthropogenic sources, in: Mercury Fate and Transport in the Global Atmosphere: Emissions, measurements and models, edited by: Pirrone, N. and Mason, R., Springer, US, 1-47, 2008.

Poissant, L. and Casimir, A.: Water-air and soil-air exchange rate of total gaseous mercury measured at background sites, Atmos. Environ., 32, 883-893, 1998.

Rytuba, J.: Mercury from mineral deposits and potential environmental impact, Environ. Geol., 43, 326-338, 2003.

Schlüter, K.: Review: Evaporation of mercury from soils. An integration and synthesis of current knowledge, Environ. Geol., 39, 249-271, 2000.

Schroeder, W. H. and Munthe, J.: Atmospheric mercury - an overview, Atmos. Environ., 32, 809-822, 1998.

Sholupov, S. E. and Ganeyev, A. A.: Zeeman atomic absorption spectrometry using high frequency modulated light polarization, Spectrochim. Acta Part B: Atom. Spectrosc., 50, 1227-1236, 1995.

Song, X. and Van Heyst, B.: Volatilization of mercury from soils in response to simulated precipitation, Atmos. Environ., 39, 74947505, 2005.

UNEP: The global atmospheric mercury assessment: Sources, emissions and transport., UNEP-Chemicals, Geneva, 2008.

Wang, S., Feng, X., Qiu, G., Wei, Z., and Xiao, T.: Mercury emission to atmosphere from Lanmuchang $\mathrm{Hg}$ - $\mathrm{Tl}$ mining area, southwestern Guizhou, China, Atmos. Environ., 39, 7459-7473, 2005.

Wang, S., Feng, X., Qiu, G., Fu, X., and Wei, Z.: Characteristics of mercury exchange flux between soil and air in the heavily air-polluted area, eastern Guizhou, China, Atmos. Environ., 41, 5584-5594, 2007a.

Wang, S., Feng, X., Qiu, G., Shang, L., Li, P., and Wei, Z.: Mercury concentrations and air/soil fluxes in Wuchuan mercury mining district, Guizhou province, China, Atmos. Environ., 41, 59845993, 2007b.

Xin, M., Gustin, M., and Johnson, D.: Laboratory investigation of the potential for re-emission of atmospherically derived $\mathrm{Hg}$ from soils, Environ. Sci. Technol., 41, 4946-4951, 2007.

Zhang, H., Lindberg, S. E., Marsik, F. J., and Keeler, G. J.: Mercury air/surface exchange kinetics of background soils of the Tahquamenon river watershed in the Michigan Upper Peninsula, Water Air Soil Poll., 126, 151-169, 2001.

Žižek, S., Horvat, M., Gibičar, D., Fajon, V., and Toman, M. J.: Bioaccumulation of mercury in benthic communities of a river ecosystem affected by mercury mining, Sci. Total Environ., 377, 407-415, 2007. 